\title{
POST-COMMUNIST LAND USE CHANGES RELATED TO URBAN SPRAWL IN THE ROMANIAN METROPOLITAN AREAS
}

\author{
Ines Grigorescu ${ }^{\mathrm{a} *}$, Bianca Mitrică ${ }^{\mathrm{a}}$, Gheorghe Kucsicsa ${ }^{\mathrm{a}}$, Elena-Ana Popovici ${ }^{\mathrm{a}}$, \\ Monica Dumitrașcu ${ }^{\mathrm{a}}$, Roxana Cuculici ${ }^{\mathrm{b}}$ \\ ${ }^{a}$ Institute of Geography, Romanian Academy, Bucharest, Romania \\ ${ }^{b}$ Faculty of Geography, University of Bucharest, Bucharest, Romania
}

\begin{abstract}
The landscape pattern of the Romanian urban system has experienced significant transformations as a result of the rapid and irreversible changes undertaken after the fall of the communism. In Romania almost $34 \%$ of its total population are living in metropolitan areas. The paper is aiming to analyse the landscape-related challenges land-use/landcover changes in the Romanian metropolitan areas in relation with the main factors involved in the patterns of change: demographic, political and natural. Based on the investigation of relevant cartographic supports of the last 20 years, the authors are making use of different GIS methods in order to conduct a series of complex analysis of the spatial-temporal landscape challenges. The paper will mainly focus on four metropolitan areas considered as case-studies: the capital-city (Bucharest) and the three functional metropolitan areas (Oradea, Iași and Constanța), each metropolitan area is facing different patterns and causes of change.
\end{abstract}

Key words: Landscape challenges, Land-use dynamics, Post-communism, Metropolitan areas, Romania.

Article Info: Manuscript Received: February 29, 2012; Revised: May 11, 2012; Accepted: May 15, 2012; Online: May $29,2012$.

\section{Introduction}

Over the last twenty years, the development of the post-socialist urban systems has been characterized by substantial restructuring processes facing the growing challenges of urban sprawl and the associated environmental consequences in terms of land-use/land-cover changes, loss of natural vegetation, habitat fragmentation etc. Nearly half of the world's population lives in urban areas (projected to reach $60 \%$ by 2030) out of which about $80 \%$ in Europe. These big city regions are confronted by complex, interdependent environmental, social and economic issues that have local and global dimensions. Here, land-use changes, spatial dynamics, such as urban sprawl, polycentric development and urban shrinkage can be noticed simultaneously (Kamal-Chaoui, Robert, 2009; URBAN-NET, 2010).

\footnotetext{
${ }^{*}$ Corresponding author:

Address: Institute of Geography, Romanian Academy, Dimitrie

Racoviţă Str., no. 12, sector 2, Bucharest, 023993.

Telephone: +40.21 .313 .5990$

Email: inesgrigorescu@yahoo.com
}

Many countries in Central and Eastern Europe have been undergoing radical socio-economic transformations following the collapse of the former "Eastern Bloc" and totalitarian regimes, in terms of marked economic changes and intensive spatial development. Just like other major post-communist urban systems (e.g. Budapest, Prague, Warsaw etc.), Romanian Metropolitan Areas are still experiencing profound transformations which have triggered a dynamic reorganization of the urban/suburban landscape (Soós and Ignits, 2003; Degorska, 2004; Sykora, 2006; Janáč et al., 2010). At the metropolitan level several phases of evolution have been identified (van den Berg et al. 1982; Petsimeris, 2002): urbanization, suburbanization, deurbanization (counterurbanisation), and reurbanization, defined as the relationship between growth and decline of the urban center and the urban fringe. The second phase (suburbanization) is characterized by a strong process of deconcentration of both population and economic activities from the centre towards the hinterland. This process characterised the territorial expansion of towns in several Southern European (Petsimeris, 2003) or former communist countries (Turnock, 1998; Soós and Ignits, 2003; Degorska, 
2004; Ourednicek, 2007; Sykora and Ourednicek, 2007; Hirt, 2008; Leetmaa, 2008, Tammaru et al., 2009; etc.) describing a general model of development by linear tendencies of urban development along the main transportation axes as well as the appearance of residential areas outside the towns.

Land-use/land-cover changes can only be understood by a profound comprehension of both land use history and spatial variability of biophysical, socio-economic and political factors on one hand and its actors on the other (Soler and Verburg, 2010). Therefore, assessing land-use changes is a complex process involving different input data especially when dealing with larger intervals and a wide range of factors, generating various environmental impacts (Bicík et al., 2001; Styck, 2007).

When discussing land-use dynamics in Romania, relating them to a broad spectrum of environmental drivers (natural, socio-economic, political etc.) is compulsory. The studies undertaken at national, regional and local level revealed the strong connection between these driving forces of change and the triggered environmental transformations (Bălteanu et al., 2004; Bălteanu et al., 2005, Bălteanu and Grigorescu, 2006; Popovici, 2008; Bălteanu and Popovici, 2010; Popovici, 2010 etc.).

Assessing land-use dynamics in metropolitan areas, defined as complex inter-linkages between rural and urban systems, is critical in managing regions affected by rapid growth. In most cases, changes in land-use patterns are driven by individual decisions regarding location and land use of individual parcels. Jointly, these individual-level changes generate regional patterns of urbanization and other related changes that have broad impacts on communities, local and regional economies, and environment (Irwin, 2003). Some of these transformations might have serious consequences on the quality and structure of land (excessive fragmentation of the agricultural terrain, the emergence of individual or subsistence farms, inadequate agricultural practices, severe degradation of farming land, etc.) (Turnok, 1998; Kuemmerle et al., 2009; Bălteanu and Popovici, 2010).

\section{Methods and data}

Land-use dynamics is the expression of the causal relationships between man and territory, thus understanding their complex inter-linkages requires spatial and time referenced information in order to measure the physical dimension of metropolitan phenomenon.

Therefore, statistical data topographic maps, aerial photographs and satellite images were used to identify the land-use dynamics in terms of change (conversion). Digital transportation data and tabular census data were also incorporated into the database to provide a more complete picture of changes occurring over time. A time-series animation of urban growth for the urbanized region depicts the alarming growth patterns the area experienced between the mid-180os and the 1990 .

The present research is dealing with the specific trends in land-use changes within the last almost twenty years (post-communist period) which has determined the most radical changes, especially with respect to agricultural land, forest areas, and residential development. The paper is trying to relate physical patterns of land use/land cover to the underlying social processes (Donnelly, 2010) in order to identify possible differences in land-cover change connected to spatial policies of land occupation (Soler and Verburg, 2010) and stress the causes and effects of environmental changes after the fall of the communist regime as well as the complex temporal analysis of the urban-rural interface in relation with the most important factors of change.

The study relies on three different types of data necessary to assess the land transformations experienced by the Romanian metropolitan areas, with a special focus on Bucharest, Oradea, Iaşi and Constanţa as the most representative in terms of spatial development and related environmental consequences: spatial data, statistical data and field surveys. The spatial data consisted in GIS processing and investigating of the most relevant cartographical documents for the analysed period at various spatial scales: Topographic maps (1990), scale 1:100 ooo; Corine Land Cover - CLC - (1990 and 2006), scale 1:10o ooo and aerial photographs. Additionally, statistical data supplied by National Institute of Statistics, Romanian Statistics Yearbooks 1990-2008 as well as field surveys were taken into consideration.

In order to retrace and analyse land-use changes over the last twenty years primarily, the authors made use of several GIS procedures and techniques in order to draw up the land-use maps for two relevant time intervals for the selected metropolitan areas (1990, 2006). In this sense, the authors used IDRISI ANDES (Integrated GIS and Image Processing System) software, a geographical system considered as leading tool in raster analytical functionality (Eastman, 2006). Spatial data processing was achieved using Land Change Modeller / Change Analysis, and integrated tool for analysing land-cover change. The selected land cover/use categories for the current analysis were the following: arable lands, vineyards, orchards, pastures, discontinuous urban fabric, forest and semi-natural areas, sport and leisure facilities, industrial and commercial units and water bodies. Hereby, complex investigation were 
undertaken in terms of net change (for all the land use categories as well as for the most relevant ones according to particular features of each metropolitan area taken into account), gains and losses analysis between 1990 and 2006, and map transition/conversion (for surfaces of over 300 ha and for the most dynamic land use categories).

Given the non-uniform and sometimes incomplete information, the different mapping scales and the particularities of the study areas (plain and low hilly/plateau regions), some adjustments were to be taken into account. Therefore, in order to assume an accurate comparative analysis of land-use changes between the selected case-studies, the authors made use of other subsidiary resources: cartographical maps (1990, scale 1:50 ooo), satellite images etc.

\section{Metropolitan development in Romania}

Over the last twenty years urban development in Romania turned to complex territorial structures such as metropolitan areas. Even though the geographical literature defines metropolitan areas as spaces under the influence of urban centres that have macro-regional functions and whose population exceeds 1 million people (Erdeli et al, 1999), in Romania, metropolitan areas, except the Capital city, are well under 400,000 inhabitants and polarise spaces that have fewer than 1 million inhabitants. For that matter since 2001 it was introduced in Romanian legislation the joint character of administrative- territorial structures as a basis to defining the metropolitan territory as the zone (area) realized through association, by voluntary partnership between the main urban centres (the capital city of Romania and the first-rank municipalities) and adjoining the urban and rural settlements situated at distances up to $30 \mathrm{~km}$, that established cooperation relations at different levels (Law no. 351 of July 2001; National Territory Management Plan, Section IV Settlements). Moreover, in order to support the spatial evolution of the rural-urban interface it was encouraged the transformation of communes, viewed as local polarisation cores, into towns, as well as other regulations able to confer new approaches related to metropolitan organization and management (Law no. 350/2001, Ordinance no. 53/2002 and Law no. 286/2006).

In the Romanian urban system 21 towns have developed or intend to develop metropolitan areas but only one (in terms of population number) Bucharest - meets the requirements of both international and Romanian classification. The other 20 towns have developed such urban systems based on the legislative context which supports metropolitan development rather by the joint character of the administrative units and founded on the governmental or local authorities support (Figure 1). Among these towns only three (Oradea, Iaşi and Constanța) have gained the functional and legal metropolitan area status, reason of which, besides the capital-city, are taken into consideration by the present study for a more detailed approach.

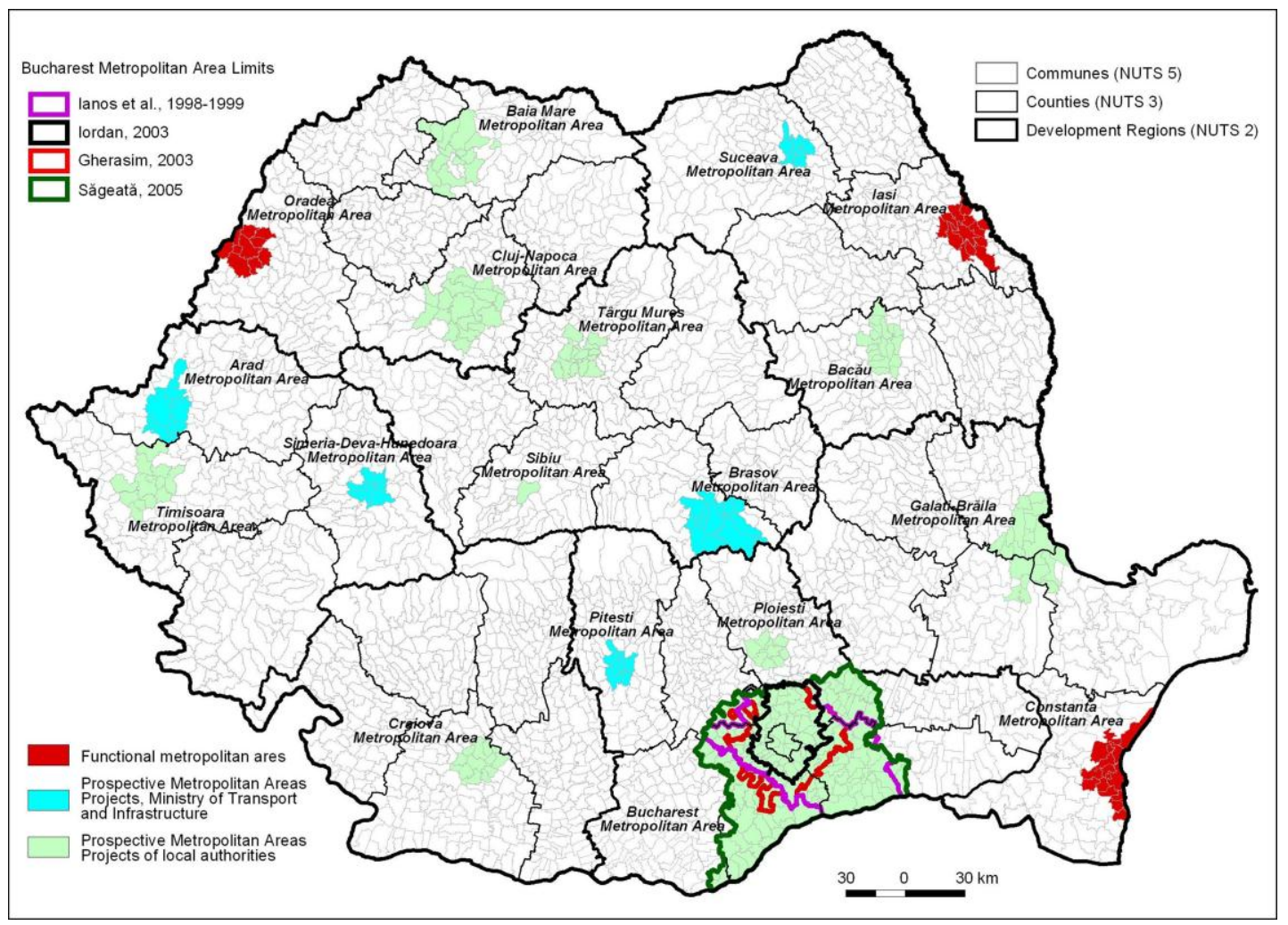

Figure 1. Metropolitan development in Romania 
Therefore, Oradea Metropolitan Area was the first functional metropolitan territory established in Romania (since 2001). It gathers about 240,000 inhabitants on an administrative area of 70.848 ha. Oradea Metropolitan Area has been a member of METREX (The Network of Metropolitan Areas and Regions) since the beginning of 2006, thus having the possibility of implementing local and regional projects. Iaşi Metropolitan Area, located in the northeastern part of the country, 12 kilometers from the border to the Republic of Moldova, has developed as the second functional metropolitan system, since 2004. It includes the town of Iaşi and 13 surrounding villages spanning over a 79,917 ha area with a population of over 400,ooo inhabitants. Constanţa Metropolitan Area was developed around the second largest city in Romania as an almost continuous urban axis connecting Năvodari and Tuzla localities, stretching north-south alongside the Black-Sea seashore and having both a tourist and industrial harbour-like profile. It is the third established metropolitan area (since 2006) being made up of 14 localities totalling less than 450 ,ooo inh. on a surface of about 99,106 ha. Bucharest Metropolitan Area can be easily seen as detached from the rest of the cities due to its distinct position within the urban national and regional system. Several variants have been proposed by now in terms of scientific and political point of view (Bălteanu and Grigorescu, 2005). It covers a surface of 532,156 ha and gathers over $2,500,000$ inhabitants $(11.5 \%$ of the total population of Romania).

\section{Post-communist landscape challenges related to land-use dynamics}

The socio-economic transformation determined by the fall of the communist regime experienced by the Central and Southeast European states over the last twenty years had facilitated profound changes in terms of intensive spatial development (urban/suburban sprawl) which have affected the evolution of land use structure and patterns (Janáč et al., 2010). Later, the EU accession opened the former communist cities and surrounding territories to new challenges related to urban phenomena, turning them into connection points at European level by promoting cohesion and competitiveness for a polycentric metropolitan development (Grigorescu, 2010). Therefore, understanding the role of certain key factors in the complex process of land-use dynamics is compulsory in assessing the main traits of landscape challenges during the post-communist period.

\section{Key driving forces of land-use dynamics over the post-communist period}

The driving forces of land-use/land-cover changes are set off by the social, economic, and political processes embedded in human societies that may include changes in population or consumption that result in different land resource demands, changes in technology, government policies, or economic conditions (Napton et al., 2010). A better understanding of the key driving forces of land transformations and how they interact in a certain territory is extremely important in understanding the related environmental outcomes.

The main driving forces of land-use changes in the Romanian metropolitan areas are related to a wide range of natural and socio-economic factors which could be summed up as: political drivers which are directly responsible for land-use change pattern in the area (political decisions influenced the property status, type of exploitation, and also, landcover/land-use conversion) (Bălteanu and Popovici, 2010), demographic drivers (population growth and expansion of settlements) and natural drivers (the main physico-geographical features).

\section{Political drivers}

Since the fall of the communist regime (December, 1989), an extremely dynamic epoch with intense consequences in terms of land-use changes had underway, strongly affecting the Romanian territory. These changes have brought about, as major general outline, the transition from a centralised economic system to the market economy triggering restructuring processes in all fields of activity leading to new characteristics and dimensions to the urban phenomenon.

The first phase of this period, the so-called transition period (1990-2003) is related to the transition from state and collective property to private ownership through the decollectivisation and privatisation of agriculture by means of a wide range of "land laws". The changes related to these two processes determined structural relocations of the different land use categories with direct impact on agriculture and land fund. Hereby, decollectivisation was put into motion by means of one of the first transition laws Law No 18/1991 (also known as The Land Law) and the additional lows (169/1997, 1/200o) which had in view to reconstitute the right to ownership of collective farm members, of their successors and of other categories of persons. Concurrently, through privatisation, which went together with decollectivisation, the state-owned lands passed into the ownership of private economic 
agents. By means of Law no. 15/1990 and Law no. 31/1990 the reorganisation of state-owned economic units as autonomous companies and trading companies was undertaken. Furthermore, the former state farms (IAS) were converted into trading companies according to Laws no. 198/1999 and no. 46/200o. Concurrently, the destruction and the sales of the collective assets of former Agricultural Production Cooperatives and State-owned Agricultural Farms took place leading to strong land fragmentation and land speculation tendencies (Bălteanu et al., 2004; Bălteanu et al., 2005).

The second stage - the so-called post-transition period (2003-2010) - involves a new series of territorial changes and transformations related to Romania's joining the European Union. Due to the variety of measures and policies Romania had to assume, two different periods could be distinguished: the pre-EU accession (2000-2007) and the post-EU accession (2007-present).

During the pre-EU accession stage, in order to gain European Union membership Romania had to comply with the European legislation, adopt progressively an agricultural policy and create an institutional framework compatible with the Community's Common Agricultural Policy (CAP). During this period several EU-funded programmes were put in place, the most important ones being PHARE, ISPA and SAPARD, mainly focused on the development of rural areas.

After 2007 (post-EU accession), as Romania had to implement new Common Agricultural Policies, agriculture would develop within a new context, which meant complying with such standards as environment protection, ensuring the safety of food, as well as animal protection and health through different funding means.

In conjunction with these national level complex socio-economic transformations which have affected mostly the agricultural sector, Romanian metropolitan areas experienced a wide variety of changes related to land-use dynamics, with a special focus on agricultural land.

\section{Demographic drivers}

After the fall of the communist regime, the Romanian urban system underwent a restructuring process imprinting new features and dimensions to the urban phenomenon. Under the new socio-political context, the suburbanization process emerged, thus being characterized by a strong of deconcentration of both population and economic activities from the centre towards the hinterland triggering the so-called urban diffusion (Grigorescu, 2008). Therefore, the population growth which unfolded during the communist period registered important variations after 1990. This process had evolved concurrently with the urbanisation and suburbanization processes, respectively. This dynamics was mainly related to the huge disparity in size and potential between the core cities of the analysed metropolitan areas and the other components of the metropolitan system (Figures 2, 3, 4 and 5).

Compared to other Romanian urban systems, these metropolitan areas witnessed a minor increase, especially after 2002-2005 related to and improvement of living standards which determined a preference of people for the suburbs (suburbanisation process). Moreover, a decrease of the town population and an increase of the metropolitan area.

In the Romanian Metropolitan Areas, a higher population dynamics is registered in surrounding area of the capital-city determined by the preference of people for the suburbs, seen as the most desired residential areas (Buftea, Mogoşoaia, Corbeanca, Voluntari, Bragadiru etc. for the Bucharest Metropolitan Area; Sânmartin, Osorhei for Oradea Metropolitan Area; the north-eastern and northwestern localities for Iaşi Metropolitan Area; northern and southern areas for Constanţa Metropolitan Area etc.).

This process also stimulated the conversion of some rural settlements from their metropolitan area into urban settlements in order to attenuate the hypertrophic tendency of some of the towns. Out of all the Romanian metropolitan areas, the case of Bucharest is by far the most noteworthy. Over the last twenty years, out of the total of 14 towns, more than half were declared urban ( 4 in 1989 and 6 in and 2005).

These changes related to settlement status favoured in most of the cases important land use transformations especially in terms of conversion from agricultural to residential, commercial or other land use categories.

\section{Natural drivers}

The position of Romanian metropolitan areas, mainly in plain and low hills/plateaus relief units, explains the emergence of their urban systems since early periods. Bucharest Metropolitan Area located in the south-eastern part of Romanian Plain, also known as Lower Danube Plain (Bălteanu et al., 2006). This territory has always been an agricultural rural space because of its favourable geographic, social and historic circumstances characteristic of the space situated between the Carpathian Mountains and the Danube River (Geografia României, vol. V, 2005), which explains the prevalence of agricultural land, mainly arable (over 70\%). Over time, as a result of the 


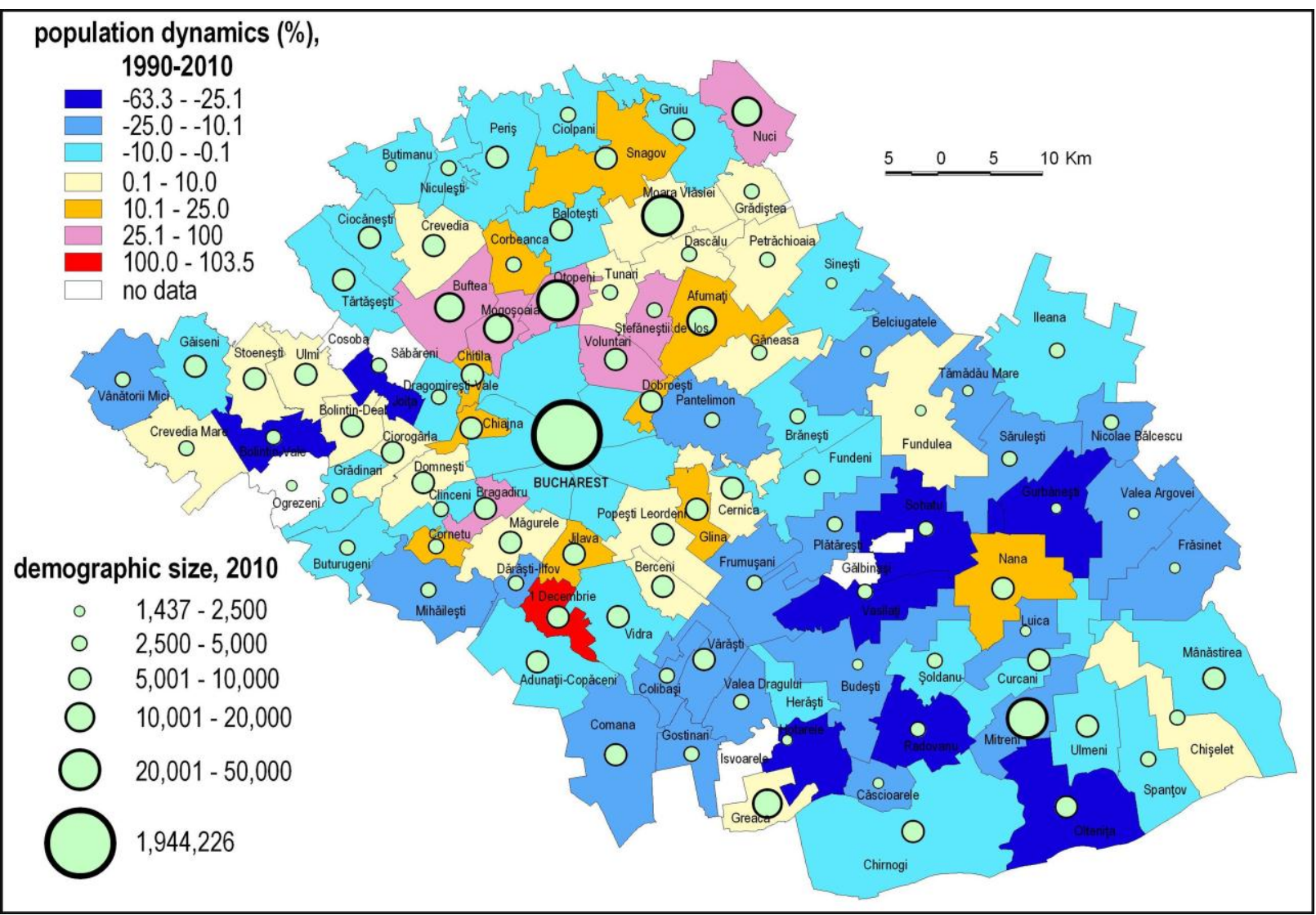

Figure 2. Population dynamics and demographic size of settlements in the Bucharest
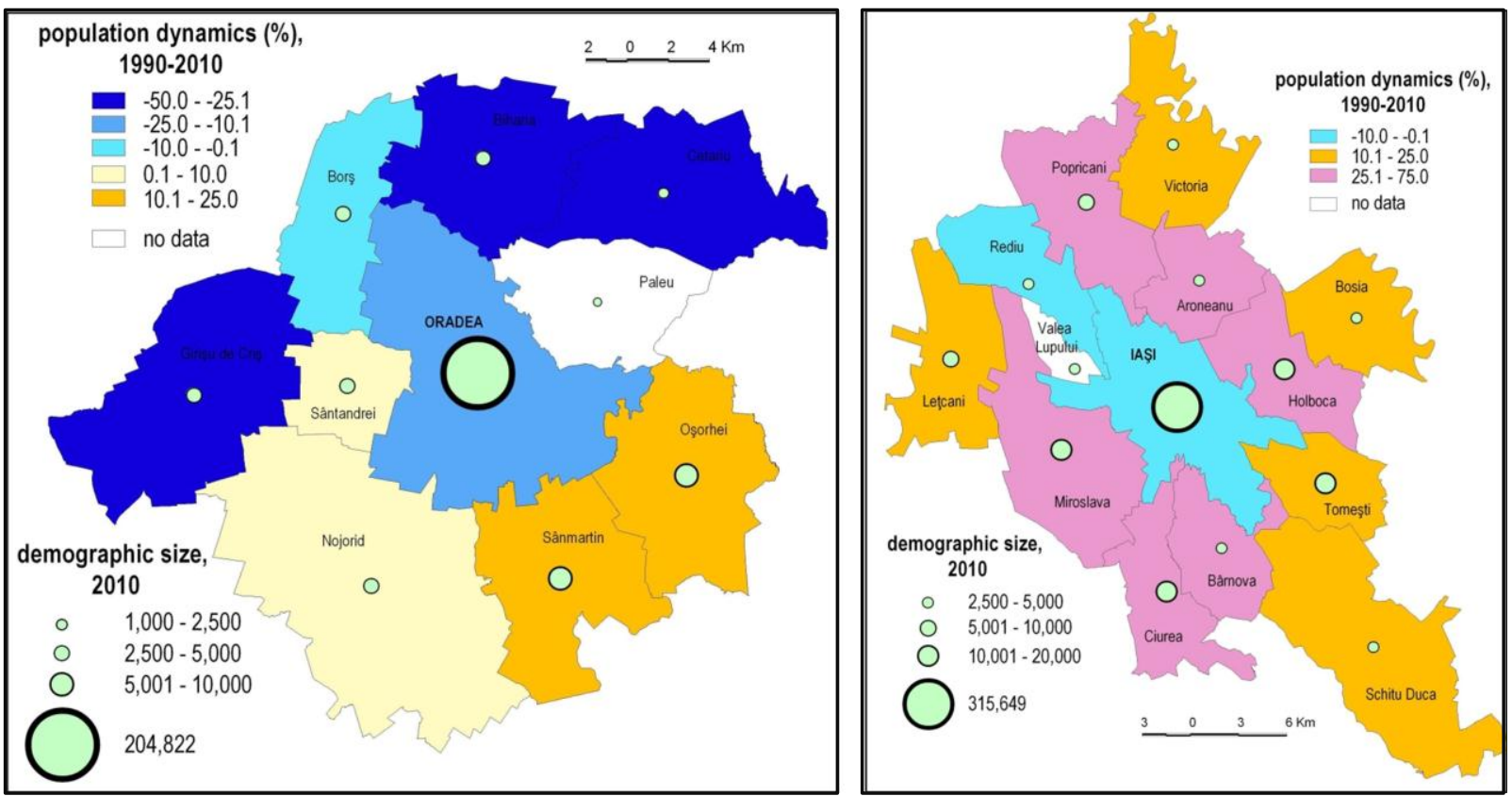

Figures 3, 4. Population dynamics and demographic size of settlements in the Bucharest (left) and Iași (right)

physical peculiarities of this relief unit and intense man-made changes, radical transformation of the terrestrial cover and land use were experienced, mostly related to agricultural practices.

Oradea Metropolitan Area is developing at the boundary between the Crişana Hills, which appear like an alternation of elongated summits and submontane hills inside gulf-like depressions (e.g. Oradea-Borod Depression crossed by the Crișul Repede River) and Crişana Plain which shows numerous deserted channels, swamps with peaty soils and lakes. Much of the Plain has been turned into 
agricultural land (Bălteanu et al., 2006). After being established as legal metropolitan area, Oradea was exposed to a wide range of landscape challenges related to land use conversion from agricultural to other land use categories.

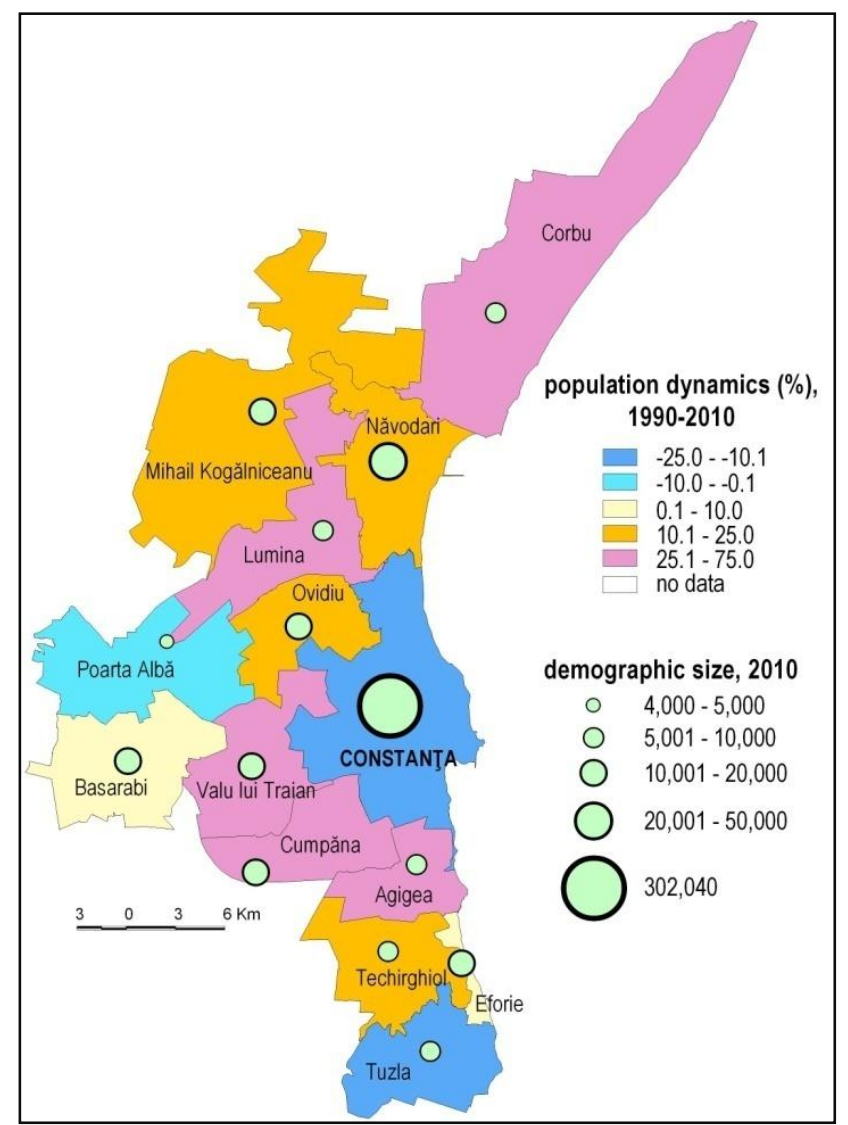

Figures 5. Population dynamics and demographic size of settlements in the Constanța

Iaşi Metropolitan Area is situated in the northeast of Romania in a hill-like unit, with a general north-east - south-west inclination. The northern part of the metropolitan area lies in the Jijia-Bahlui Plain (100-150 m altitude) and the southern part on the so-called Central Moldavian Plateau (300-350 m altitude). The two relief units are separated by a monocline structure characterized by cuesta alignments (Coasta Iaşiului with nearly $100 \mathrm{~km}$ long) (Bălteanu et al., 2006). Therefore, the reduced altitudes, the monocline structure with long and gentle inclinations separated by large terrace valleys stands for the largely agricultural land use (mainly arable and vineyards).

Constanța Metropolitan Area, is overlapping the eastern part of the South-Dobrogea Plateau (150-200 $\mathrm{m}$ altitude) corresponding to some flat plateau-like interfluves with a tabular structure and the Romanian Black Sea Coast, with cliffs cut into limestone and loessoid deposits elevated at some $10-35 \mathrm{~m}$ dominating the strips of beach. Usually the cliffs are fragmented into narrow valleys with fluvial limans at their mouths (Bălteanu et al., 2006). This explains the predominant agricultural land use of this metropolitan area territory coupled with urban sprawl related to tourist development.

Land-use dynamics in the Romanian Metropolitan Areas. Case-studies: Bucharest, Oradea, Iasi and Constanta.

Present-day landscapes are the result of continuous challenges to which they are exposed triggered by a broad spectrum of transformations related to human intervention. Over the last twenty years, under the influence of various causal factors and interaction, different consequences related to land-use dynamics are becoming visible in the structure of the land, the size and density of the plots, land management, environmental quality etc. In the Romanian Metropolitan Areas land transformations trigger a wide range of environmental consequences from biophysical (land/soil degradation and erosion, biodiversity loss, habitat fragmentation etc.) to land structural changes out of which land-use dynamics, land-use conversion, changes in the type of property, land abandonment and fragmentation, abandonment of land reclamation works, urban residential sprawl stand out.

By its position in the south-eastern part of the Romanian Plain, which has always been the main Romanian agricultural area, Bucharest Metropolitan Area displays almost similar environmental features characterised by a prevailing proportion of arable land as compared with the other land use categories. Over the analysed period (1990-2006) significant changes were registered. As from 1990, the fall of the communist regime led to a series of radical changes in all the fields of activity which determined important transformations in terms of land use dynamics. The CORINE Land Cover, 1990-2006 maps reveal a dramatic drop of agricultural land (of almost 8 ,ooo hectares). The bulk of this decrease was mainly the result of redistribution among other land use categories: pastures (nearly 5,00o ha due mainly to land abandonment), discontinuous urban fabric (about 1,00o ha for the new residential entities) and industrial and commercial units (almost 1,00o ha for logistic parks, hyper-markets etc.) located mainly in the surroundings of the Capital-city, the northwestern and western parts of the metropolitan area following the general trend of suburbanisation (Figure 6). 


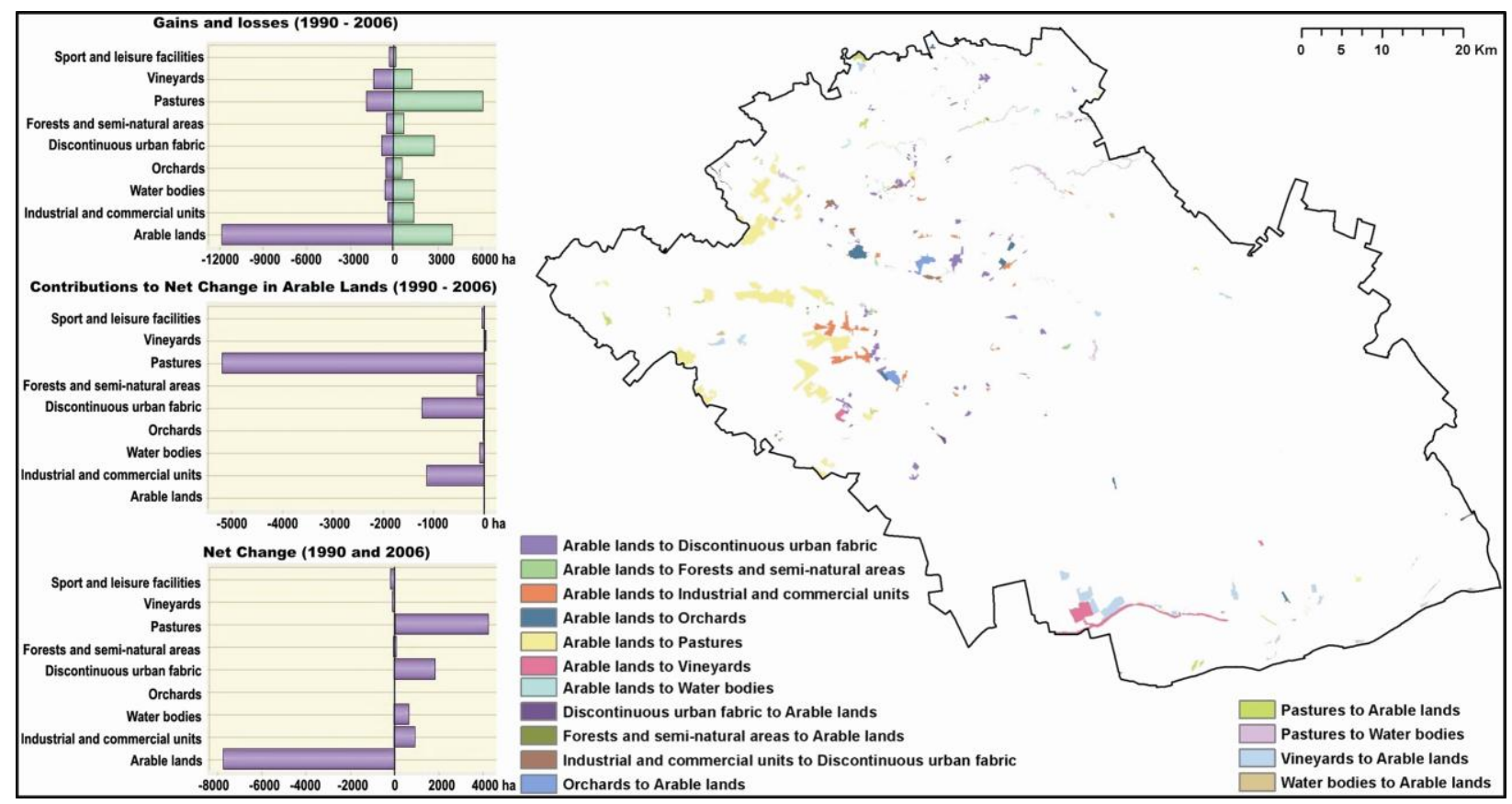

Figure 6. Land use conversion in the Bucharest Metropolitan Area

(CORINE Land Cover, 1990 and 2006)

Development of new dwellings complexes most often was not accompanied by adequate infrastructure development (roads, sewerage and water supply networks, etc.). Also, the economic development had transformed the society into the consumption-oriented one increasing the demand for new services, thus leading to the conversion of larger surfaces of agricultural land into other land use categories (shopping, entertainment, leisure).

Oradea Metropolitan Area experienced an increased land-use dynamics in terms of change and conversion. The most dynamic land use categories which registered significant shrink were: vineyards with about 1,200 ha, water bodies with more than 800 ha and pastures with almost 500 ha. Vineyards conversion was made largely to orchards and arable lands (Figure 7).

In this region, the conversion of vineyards into orchards could be ascribed as a mistake in interpreting the satellite images used for Corine Land Cover 2006 database. Thus, the orchards found on the 2006 map could be in reality vineyards. None of these two land use categories have been increased. The analysis undertaken based on of the NUTS 5 level statistical data revealed a significant shrink of the surfaces covered by vineyards and orchards.

Iaşi Metropolitan Area witnessed an extremely dynamic territorial evolution over the analysed interval affecting almost all the land use categories. Among all, the deepest shrink was registered by the arable lands (almost 4,0oo ha), pastures (over 2,000 ha) and vineyards (nearly 2,ooo ha); they were turned into other land use categories, mainly discontinuous urban fabric (almost 1,00o ha) and industrial and commercial units (nearly 800 ha) (Figure 8).

Concurrently, one could notice a quite significant shrink of pastures (over 4,00o ha) and a slight decrease of vineyards (above 2,00o ha) due to their abandonment and transformation into other land use categories, mainly discontinues urban fabric and arable land.

Constanţa Metropolitan Area was very well known during the communist period for the large surfaces covered with arable land and orchards, mainly peaches and apricots. The orchards were abandoned on extended surfaces (almost 1,500 ha), followed by arable land (almost 1,200 ha) and pastures (nearly 900 ha) and turned into other categories, generally discontinuous urban fabric (1,200 ha) and industrial and commercial units (almost 8oo ha) (Figure 9).

The patterns of land-use dynamics after 1990 lines up with the trends experienced by the other European post-communist countries. Therefore, although the category of arable land continued to fall in all the analysed metropolitan areas (up to 8,00o ha in Bucharest Metropolitan Area), the pattern of redistribution among other land use categories mainly pointed to residential/commercial uses on one hand or pastures (related to land abandonment), on the other.

Additionally, due to the privatisation and excessive fragmentation of state farms, the collapse of agricultural market occurred generally leading to the decline of most of the permanent agricultural crops (vineyards, orchards). This tendency was seconded, in some extent, by a decrease of permanent grasslands. 


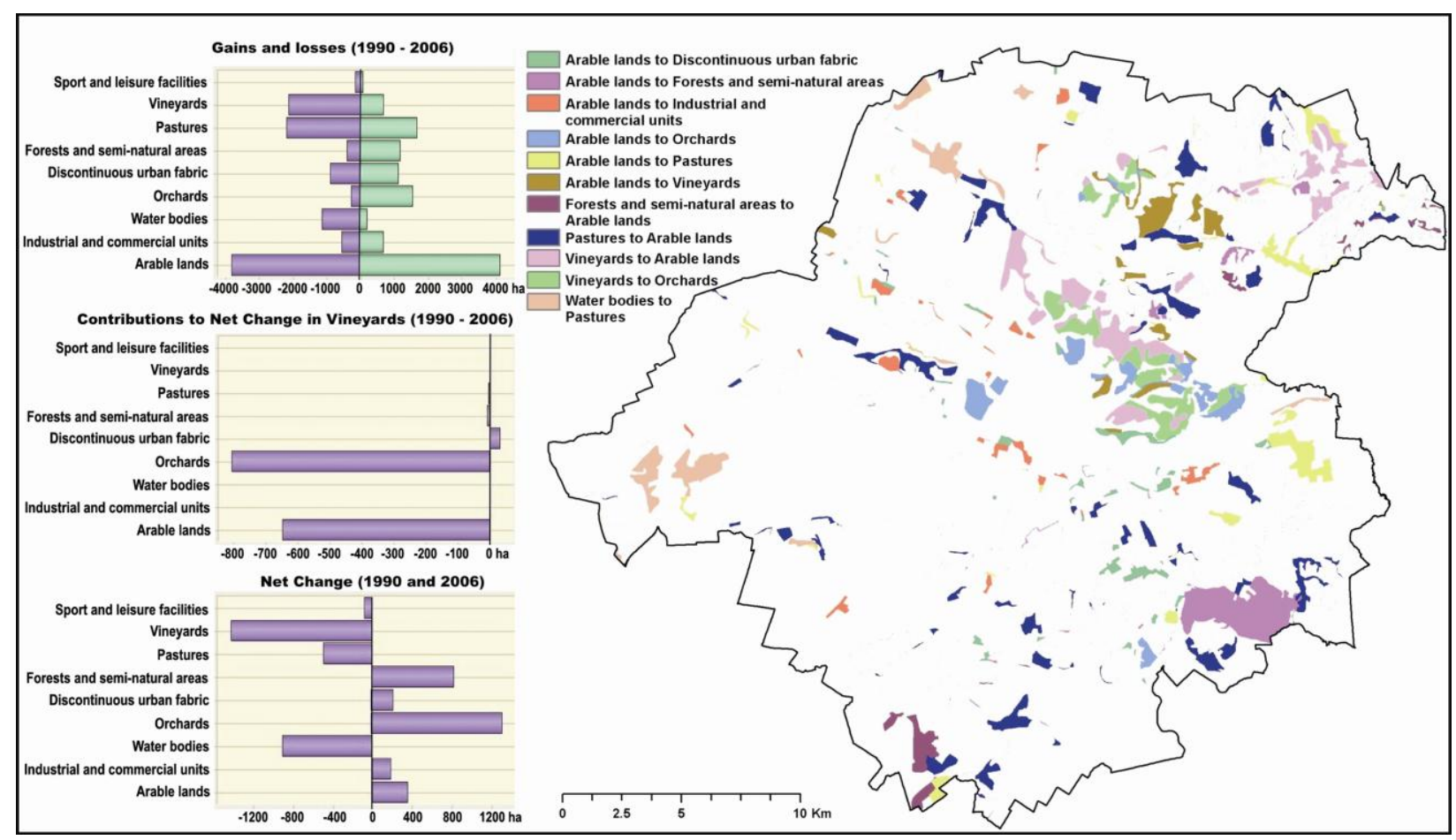

Figure 7. Land use conversion in the Oradea Metropolitan Area

(CORINE Land Cover, 1990 and 2006)

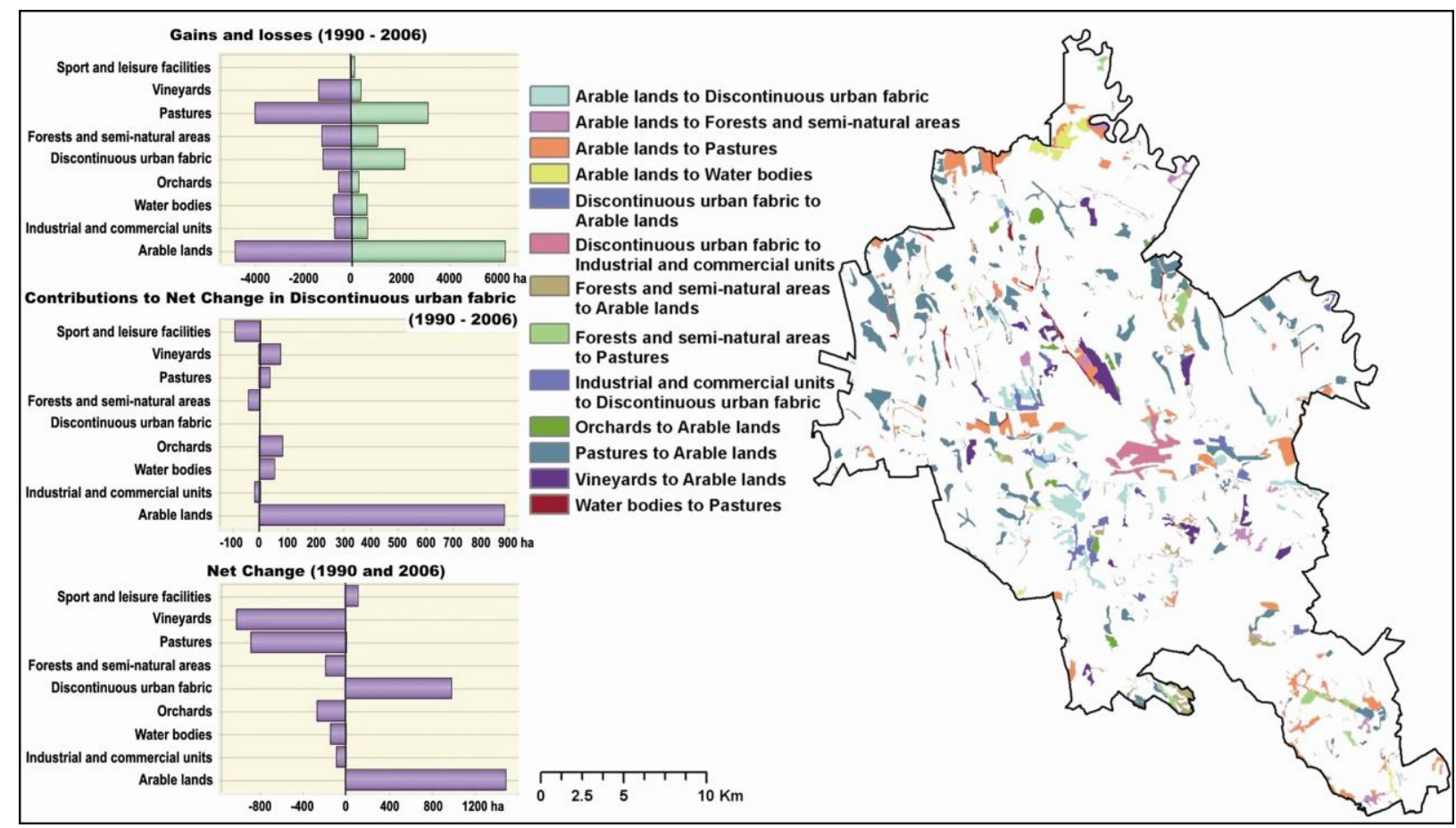

Figure 8. Land use conversion in the Iaşi Metropolitan Area

(CORINE Land Cover, 1990 and 2006)

Altogether, all these transformations led to the outburst of other areas, especially those located in the outskirts of big cities or alongside main roads or highways (residential, commercial or industrial) (Soós and Ignits, 2003; Sykora and Ourednicek, 2007; Grigorescu, 2010).
Under the deficient legislative measures related to agriculture in terms of subsidies, rental etc. lead to abandonment of less fertile soils. These changes were similar with the ones experienced by some other post-communist urban areas when, under the pressure of foreign producers (EU, USA, etc. - more intensive and more subsidized, "unfair" competitors) 


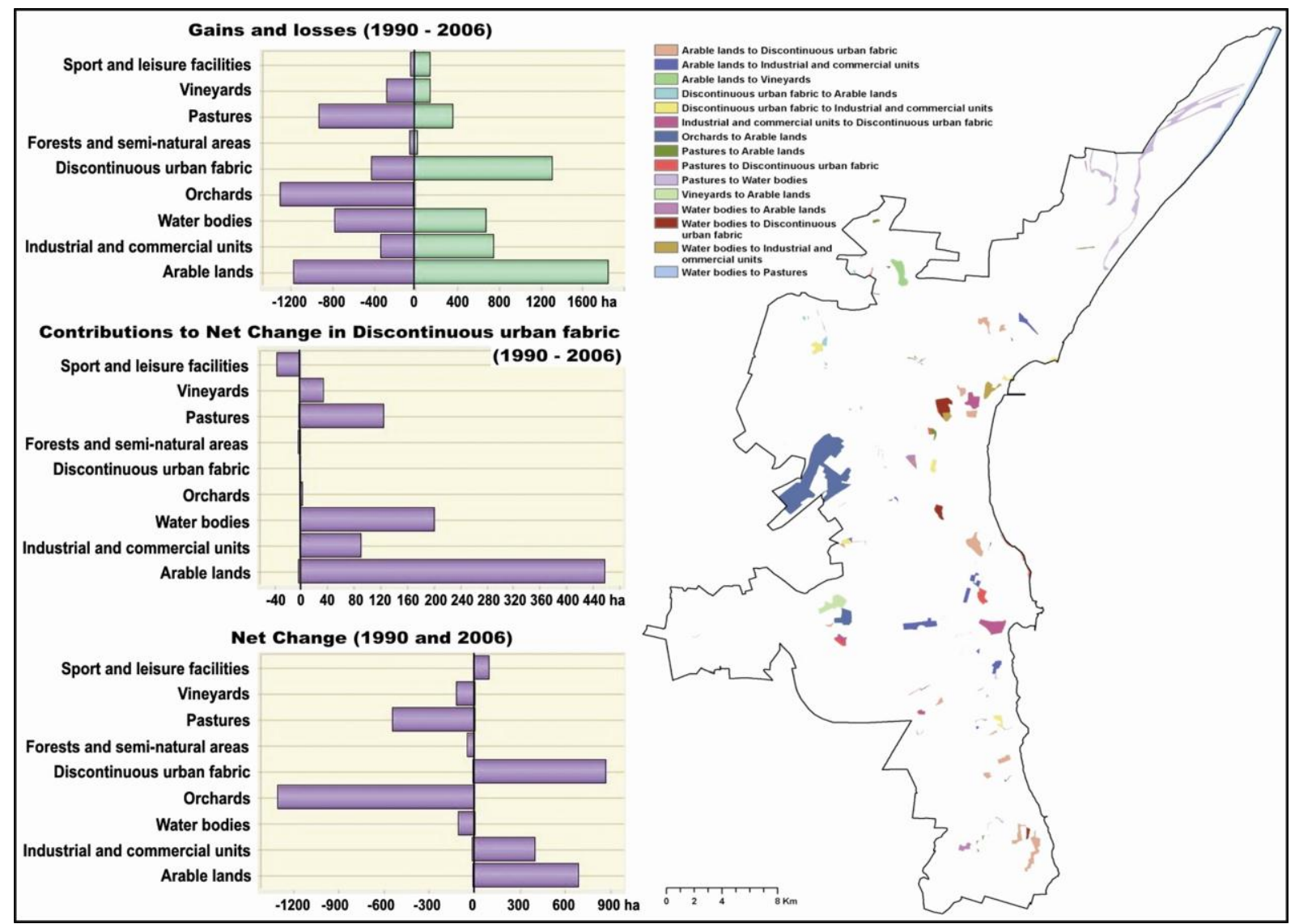

Figure 9. Land use conversion in the Constanța Metropolitan Area

(CORINE Land Cover, 1990 and 2006)

significant areas of arable land have been abandoned and turned either into permanent grasslands, forests or other areas.

\section{Main environmental consequences related to land-use dynamics}

The human-induced landscape transformations related to the post-communist land-use dynamics had brought about significant changes with respect to the type of property of agricultural and forest lands and in the type of farms. Therefore, under the application of the post-communist measures and laws, Romanian Metropolitan Area experienced radical changes in the type of property when new types of agricultural exploitations have appeared: the small and poorly equipped (individual or family) traditional peasant households (env. 2-3 hectares on an average); the agricultural businesses or trading companies (former State-owned Agricultural Farms) and the associative structures (family associations and agricultural companies with a juridical status). This new organisation of private property carries out negative effects in terms of excessive fragmentation of farming land (most of them under 2 ha), the emergence of large numbers of individual farms practicing subsistence agriculture, poor services for agriculture (irrigation, fertilisation, mechanisation, etc.), all of which have contributed to the decline of the land's productive potential and severe degradation of the quality of agricultural land (Popovici, 2010). In some situations the small plots of land are sold or when they have an attractive location they receive several other destinations (residential or commercial).

In addition, another important effect of the enforcement of agricultural laws and the related consequences is the abandonment of land improvement works, especially the irrigation systems. Considering the particularities of its geographical location and its main climatic features, Bucharest Metropolitan Area is exposed to wide variety of climatic extreme events such as heat waves inducing dryness and drought phenomena with consequences mainly on agriculture and on the water supply for irrigation (Dragotă and Grigorescu, 2010). In the general context of global climate changes, this perspective stresses even more the importance of land reclamation works in agricultural management.

Associated to the political transformations of the last twenty years, land-use dynamics triggered structural relocations and spatial dynamics mainly related to suburbanization - a dominant process in changing the landscape of post-communist 
metropolitan areas, reshaping their morphology, land-use pattern and socio-spatial structure. These new development conditions favour a booming of real estate market determining residential sprawl (individual and planned residential households "gated communities") accompanied by the emergence of huge shopping centres, hypermarkets, warehouses and industrial properties (logistic parks) (Soós and Ignits, 2003; Sykora and Ourednicek, 2007; Hirt, 2008). Under these conditions, the prices grew from few eurocents/sqm in 2000 to over 100 euros/sqm on an average in 2008.

Among all Romanian Metropolitan Areas, Bucharest ranges first when it comes to maximum land prices (eg. in 2008, in the Pipera-Tunari area, the most expensive land reached up to 1,100 euros/sq.m and in the town of Otopeni, up to 6oo-80o euros/sq.m). After the economic crisis the real-estate market collapsed and the land price dropped significantly (Table 1 ).

Table 1. Land prices dynamics in Bucharest Metropolitan Area (selection)

\begin{tabular}{|c|c|c|c|}
\hline \multirow{2}{*}{\multicolumn{2}{|c|}{ Settlement }} & \multicolumn{2}{|c|}{ Land price } \\
\hline & & $2007 / 2008$ & 2010 \\
\hline \multicolumn{2}{|c|}{ Voluntari (Pipera) } & $\begin{array}{c}300-1500 \\
\epsilon / \mathrm{m}^{2}\end{array}$ & $\begin{array}{c}200-600 \\
€ / \mathrm{m}^{2}\end{array}$ \\
\hline \multicolumn{2}{|c|}{ Magurele/Bragadiru } & $50-200 € / \mathrm{m}^{2}$ & $5-40 € / \mathrm{m}^{2}$ \\
\hline \multicolumn{2}{|c|}{ Pantelimon } & $100 € / \mathrm{m}^{2}$ & $70-80 € / \mathrm{m}^{2}$ \\
\hline \multicolumn{2}{|c|}{ Chitila } & $300 € / \mathrm{m}^{2}$ & $60-70 € / \mathrm{m}^{2}$ \\
\hline \multicolumn{2}{|c|}{ Mogosoaia } & $220-250 € / \mathrm{m}^{2}$ & $100-120 € / \mathrm{m}^{2}$ \\
\hline \multicolumn{2}{|c|}{ Buftea } & $60 € / \mathrm{m}^{2}$ & $30-40 € / \mathrm{m}^{2}$ \\
\hline \multirow[b]{2}{*}{ Otopeni } & city centre & $300-400 € / \mathrm{m}^{2}$ & $50-100 € / \mathrm{m}^{2}$ \\
\hline & $\begin{array}{l}\text { near the } \\
\text { airport }\end{array}$ & $800 € / \mathrm{m}^{2}$ & $\begin{array}{c}100-400 \\
€ / \mathrm{m}^{2}\end{array}$ \\
\hline \multicolumn{2}{|c|}{ Popesti-Leordeni } & $200 € / \mathrm{m}^{2}$ & $30-80 € / \mathrm{m}^{2}$ \\
\hline \multicolumn{2}{|c|}{ Berceni } & $200 € / \mathrm{m}^{2}$ & $50-60 € / \mathrm{m}^{2}$ \\
\hline \multicolumn{2}{|c|}{ Corbeanca } & $130 € / \mathrm{m}^{2}$ & $30-50 € / \mathrm{m}^{2}$ \\
\hline \multicolumn{2}{|c|}{ Snagov } & $300-500 € / \mathrm{m}^{2}$ & $100 € / \mathrm{m}^{2}$ \\
\hline
\end{tabular}

Source: Field surveys, interviews with local actors and real estate agencies

\section{Discussions and Conclusions}

Over the analysed period (1990-20o6) major changes have been taking place in the Romanian Metropolitan Areas involving several key drivers and a wide range of environmental consequences related to land-use structure. The complex analysis of land-use maps and other additional statistical documents in relation to the key factors of change has revealed the most significant landscape challenges related to land-use dynamics. The present study indicates a stronger connection with the socio-political factors over in the post-communist period as compared to the natural drivers which can be approached only as background in assessing land transformations.

In the Romanian Metropolitan Areas, the quantitative assessment of land use transformations reveals significant changes between 1990 and 2006 when the agricultural area kept shrinking, while built-up terrains, especially those close to the big urban centres have expanded (Bălteanu and Popovici, 2010). Hence, land-use/land-cover changes occurred amongst all land use types. Stands out as foremost conversions: arable land mainly to urban, industrial and commercial (especially in the proximity of the core-cities, along the main roads and were residential ensembles were developed); pastures to urban or industrial and commercial; orchards/vineyards to urban, commercial and industrial (mainly in the case of Constanţa, Iași and Oradea Metropolitan Areas); arable to pastures (largely related to land abandonment) etc.

The qualitative approach suggests that the most important changes were expressed by an increased diversification of land use categories and fragmentation of plots. These conflicting changes are largely caused by the lack of stability and consistency in the Romanian agricultural land use policies exerting undesirable environmental impacts. On a long term, land-use and land management practices confirm themselves as major impacts on natural resources and socio-economic development. Additionally, beyond their local impacts, landuse/land-cover changes generate cumulative environmental effects becoming integrated into the global system (Meyer and Turner, 1992; Napton et al., 2010). Taken into consideration the particularities of the study-areas, the paper could bring significant contributions not only to territorial planning and management in general but particularly to the spatial metropolitan planning in Romania.

\section{References}

Bălteanu, D \& Grigorescu, I 2006, 'The impact of Changing land Use upon the Environment in the Metropolitan Area of Bucharest. Preliminary Considerations', Romanian Review of Regional Studies - Journal of the Centre for Regional Geography, II, Cluj-Napoca.

Bălteanu, D \& Popovici, EA 2010, 'Land use changes and land degradation in post-socialist Romania', Romanian Journal of Geography, vol. 54 (2), Bucharest, Romania, pp. 95-107.

Bălteanu, D, Popescu, M \& Urşanu, (Popovici) EA, 2005, 'Land use in Romania under the Transition to the Market Economy', Analele Universităţii Bucuresti, Anul LIV, pp. 99-112.

Bălteanu, D, Popescu, M \& Urşanu, AE 2004, 'Land tenure and relations in Romania', in An International Encyclopedia of Land Tenure Relations for the Nations of 
the World, IV, The Edwin Mellen Press, ISBN Lewiston, Queenston, Lampeter, UK, o7734-65391, pp.

Bicik, I, Jelecek, L \& Stepanek, V 2001, 'Land-Use Changes and their Social driving Forces in Czechia in the 19th and 2oth Centuries', Land Use Policy, 18, No. 1, pp. 65-73.

Degorska, B 2004, 'Spatial conflicts between the shaping of open spaces and the socio-economic development in the metropolitan area of Warsaw', in András, Donát, Kovacs (eds), New Aspects of Regional Transformation and the Urban-Rural Relationship, Centre for Regional Studies of the Hungarian Academy of Sciences, Pecs, Hungary.

Donnelly, S 2010, 'Land-use portfolios and the management of private landholdings in south-central Indiana', Regional Environmental Change, SpringerLink, DOI:10.1007/s10113-010-0124-6.

Dragotă, CS \& Grigorescu, I 2010, Climatic hazards in the Bucharest Metropolitan Area. The assessment of the main extreme climatic phenomena in the Bucharest municipality and its surroundings, LAP Lambert Academic Publishing, ISBN 978-3-8433-6911-4, paperback, 108 p.

Eastman, JR 2006, Idrisi Andes - Guide to GIS and image processing, Manual Version 15, Clark Lab, Clark University, USA.

Erdeli, G, Cândea, M, Braghină, C, Costachi, S \& Zamfir D 1999, Dicţionar de Geografie Umană, Edit. Corint, București.

Geografia României 2005, vol. V, Edit. Academiei Române, București.

Government Ordinance no. 53/2002 regarding the approval of the Framework Statute of the territorial-administrative units.

Grigorescu, I 2008, 'Environmental issues in Bucharest Metropolitan Area', Journal of The Geographical Society of Hosei University, 40, pp. 11-21, Tokyo, Japan.

Hirt, S 2008, 'Suburbanizing Sofia: Characteristics of PostSocialist Peri-Urban Change', Urban Geography, Bellwether Publishing, Ltd., 755-78o

Irwin, GE 2003, Using GIS to model patterns of urban/rural land use change, Ohio Geospatial Technology Conference for Agriculture and Natural Resources Holiday Inn Worthington, Columbus, Ohio March 24-26, 2003.

Janáč, J, Jeleček, L \& Chromý, P 2010, 'LUCC in East Central and Southeast Europe post-communist countries from 1960 s to the end of the 2oth century and its historicgeographical roots', Acta Universitatis Carolinae, Geographica, no.2, 19-30.

Kamal-Chaoui, L \& Alexis, R (eds) 2009, 'Competitive Cities and Climate Change', OECD Regional Development Working Papers $\mathrm{N}^{\circ}$ 2, 2009, OECD publishing.

Kuemmerle, T, Muller, D, Griffiths, P \& Rusu, M 2009, 'Land use change in Southern Romania after the collapse of socialism', Regional Environmental Change, SpringerLink, DOI 10.1007/s10113-008-0050-z.

Law 350/20010n territory management and urbanism

Law 351/2001 to approve the National Territory Management Plan - Section IV - Settlements

Law no. 286/2006 of July 2006 amending and supplementing the Law no. 215/2001 of the local public administration.
Leetmaa, K 2008, Residential Suburbanization in the Tallin metropolitan area, Dissertation thesis, Tartu University Press, 278p.

Meyer, WB \& Turner, BL II 1992, 'Human population growth and global land-use/cover change', Ann. Rev Ecol Syst 23:39-61.

Napton, DE, Auch, RF, Headley, R \& Taylor LJ 2010, 'Land changes and their driving forces in the Southeastern United States', Regional Environmental Change, SpringerLink, 10:37-53, DOI 10.1007/s10113-009-0084-x.

Ourednicek, M 2007, 'Differential suburban development in the Prague urban region', Geogr. Ann., 89 B (2): 111-126.

Petsimeris, P 2002, 'Population deconcentration in Italy, Spain and Greece: A first comparison', EKISTIKS, the problems and science of human settlements, Defining success of the city in the 21st century, vol. 69.

Popovici, EA 2010, Piemontul Cotmeana. Dinamica utilizării terenurilor şi calitatea mediului, Editura Academiei Române, pp. 218

Popovici, EA, 2008, 'Factorii principali ai schimbării utilizării terenurilor în România în perioada postsocialistă', Revista geografică, T. XIV-XV - 2007-2008, Institutul de Geografie, Edit. Academiei Române, Bucureşti, pp. 123-128.

Premysl, S 2007, 'Selected driving forces of long-term land use changes in Czechia, Man in the landscape across frontiers', Proceedings of the IGU-LUCC Central Europe Conference.

Soler, L de Souza \& Verburg, PH 2010, 'Combining remote sensing and household level data for regional scale analysis of land cover change in the Brazilian Amazon', Regional Environmental Change, SpringerLink.

Soós, G \& Ignits, G 2003, 'Suburbanization and Its Consequences in the Budapest Metropolitan Area', Third EuroConference The European City in Transition, The City and the Region, Bauhaus-Universität Weimar, Germany, Supported by the European Commission.

Sykora, L \& Ourednicek, M 2007, 'Sprawling postcommunist metropolis: commercial and residential suburbanisation in Prague and Brno, the Czech Republic', in: Razin, E, Dijst, M \& Vazquez C (eds.), Employment Deconcentration in European Metropolitan Areas, GeoJournal Library, Volume 91, 209-233.

Sykora, L 2006, 'Urban Development, Policy and Planning in the Czech Republic and Prague', in Altrock, U, Guntner, S, Huning, S \& Peters, D. (eds.), Spatial Planning and Urban Development in the New EU Member States. From Adjustment to Reinvention, Ashgate Publishing Limited, England.

Tammaru, T, Leetmaa, K, Silm, S \& Ahas, R 2009, Temporal and Spatial Dynamics of the New Residential Areas around Tallinn European Planning Studies, 17/3, 423-439.

Turnock, D 1998, 'Romania', in Turnock D (ed) Privatization in Rural Eastern Europe. The process of restitution and restructuring. Edward Elgar, Cheltenham.

URBAN-NET Research Anthology, 2010

van den Berg, Leo, et.al. 1982, Urban Europe - A study of Growth and Decline, Pergamon Press, pp 162. 